\title{
The efficacy of mindfulness therapy and in comparison with invasive pain management techniques in cervicogenic headaches treatment
}

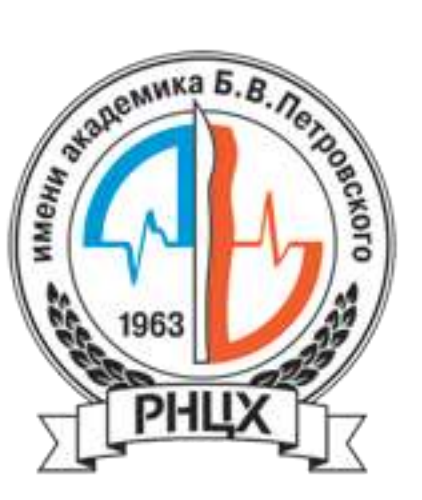

Background and Goal of Study: Headaches of cervicogenic location are $11.3-40 \%$ of all presenting symptoms in primary healthcare structure. [1] Cervicogenic headaches' $(\mathrm{CH})$ prevalence in population is $1-12 \%$. [2]

Materials and Methods: Double blinded placebo controlled study, approved by the Institutional Review Board, involved 60 amateur athletes with $\mathrm{CH}$. Patients, who attended the clinic in Sept.2016Aug.2017, were divided into three groups (20patients each) by the sealed envelope method. All patients received venlafaxitine $75 \mathrm{mg} /$ day and tizanidine 4mg/day during 12 and 4 weeks respectively. Mindfulness group was additionally educated with mindfulness meditation techniques (weekly 2-hour group sessions with following daily outside preparation and individual session for every participant), invasive pain management techniques group received $0.5 \%$ lidocaine injections in trapezius muscle trigger points (10injections with 2day intervals). The treatment effectiveness was evaluated prior to, 3 and 12 months after the treatment by pain attacks frequency and severity with the Visual Analog Scale (VAS) and Pain Catastrophizing Scale (PCS).

Results and Discussion: The mean age was $38.5 \pm 9.1,41.5 \pm 8.4$ and $42 \pm 7.6$ in the mindfulness, injections and control group, respectively. Most of respondents were females (65\%, 74\%, 79\% respectively). The pretreatment VAS score was $6.2 \pm 1.1,5.9 \pm 1.5$ and $4.9 \pm 1.8$ points and pain attack frequency $-19.2 \pm 5.4,16.6 \pm 4.9$ and $22.1 \pm 7.2$ per month, total PCS score $-21.1 \pm 9.1,19.4 \pm 8.7$ and $20.7 \pm 6.9$ points in mindfulness, injections and control group, respectively. After the 3months treatment, VAS score was significantly lower in the injections group $(1.1 \pm 0.3)$ than in mindfulness $(2.7 \pm 0.2)$ and control groups $(2.5 \pm 0.8 ; p<0.05)$, as well as total PCS score $(10.2 \pm 8.1 ; 15.5 \pm 9.2$; $16.3 \pm 10.6$ respectively, $p<0.05)$. But after the 12 -months treatment pain intensity was the lowest in the mindfulness group $(1.2 \pm 0.4)$ comparing to injections $(2.7 \pm 0.4)$ and control $(3.1 \pm 0.6, p<0.05)$ groups, as well as total PCS score $(7.5 \pm 6.1 ; 15.1 \pm 9.6 ; 14.8 \pm 7.4$ respectively, $\mathrm{p}<0.05)$.

Conclusion(s): Mindfulness therapy can significantly improve pain states in patients with $\mathrm{CH}$.

\section{References:}

1. Osipova V. Cephalalgia.2016;36(S1):72.

2. Zagorulko O. Rus J Pain 2017;1(52):90-91.
O. Zagorulko

Medical University

Centre of Surgery

SECHENOV UNIVERSITY
Benefits of mindfulness for athletes

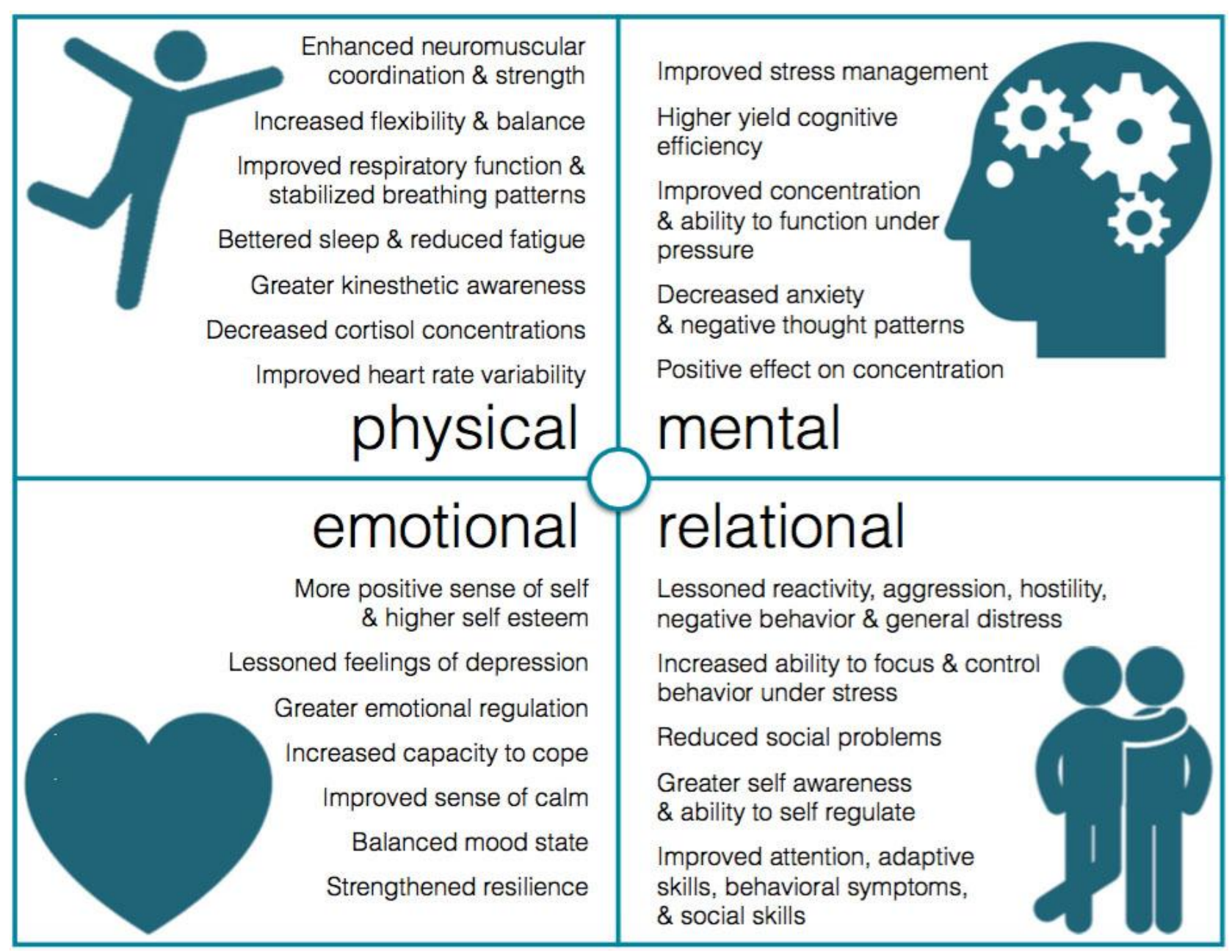

Pain intensity dynamics during treatment by VAS

Mindfulness Injections Control group, group group points

\begin{tabular}{|l|l|l|l|}
\hline Pretreatment & $6.2 \pm 1.1$ & $5.9 \pm 1.5$ & $4.9 \pm 1.8$ \\
\hline $\begin{array}{l}\text { After 3 } \\
\text { months } \\
\text { treatment }\end{array}$ & $2.7 \pm 0.2$ & $1.1 \pm 0.3$ & $2.5 \pm 0.8$ \\
\hline $\begin{array}{l}\text { After 12 } \\
\text { months } \\
\text { treatment }\end{array}$ & $1.2 \pm 0.4$ & $2.7 \pm 0.4$ & $3.1 \pm 0.6$ \\
\hline
\end{tabular}

Total PCS score dynamics during treatment

\begin{tabular}{|l|c|c|c|}
\hline & $\begin{array}{c}\text { Mindfulness } \\
\text { group, } \\
\text { points } \\
21.1 \pm 9.1\end{array}$ & $\begin{array}{c}\text { Injections } \\
\text { group, } \\
\text { points }\end{array}$ & $\begin{array}{c}\text { Control group, } \\
\text { points }\end{array}$ \\
\hline Pretreatment & $19.4 \pm 8.7$ & $20.7 \pm 6.9$ \\
\hline $\begin{array}{l}\text { After 3 } \\
\text { months } \\
\text { treatment }\end{array}$ & $15.5 \pm 9.2$ & $10.2 \pm 8.1$ & $16.3 \pm 10.6$ \\
\hline $\begin{array}{l}\text { After 12 } \\
\text { months } \\
\text { treatment }\end{array}$ & $7.5 \pm 6.1$ & $15.1 \pm 9.6$ & $14.8 \pm 7.4$ \\
\hline
\end{tabular}

